\title{
PENURUNAN KEKUATAN IMPACT BAJA ST 37 AKIBAT PENGELASAN SMAW
}

\author{
Eko Wahyudi ${ }^{1}$ \\ ${ }^{1}$ Jurusan Teknik Mesin/S1 Pendidikan Teknik Mesin, Universitas Negeri Surabaya \\ 1eko.16050524057@mhs.unesa.ac.id
}

\begin{abstract}
Abstrak- Jurnal ini menjelaskan tentang penurunan kekuatan impact dan struktur mikro pelat baja St 37 setelah dilakukan pengelasan SMAW. Penelitian ini menggunakan metode eksperimen dan metode literatur. Objek dalam penelitian ini adalah pelat baja St 37 yang mengandung sedikitnya $0,12813 \%$ karbon. Jumlah spesimen yang diujikan dalam penelitian ini adalah 27 yang mendapatkan perlakuan kuat arus berbeda. Pengelasan menggunakan elektroda E 6013 dengan variasi kuat arus 80 A, 100 A dan 120 A. Sambungan las menggunakan sambungan kampuh $V$ tunggal dengan sudut $70^{\circ}$. Setiap spesimen yang sudah dilas, dilakukan metode pendinginan dengan media pendigin oli selama 15 detik dengan posisi horizontal. Oli yang digunakan adalah meditran $S$ dengan kondisi baru untuk setiap spesimen variasi kuat arus. Spesimen baja St 37 yang dilas memiliki ketebalan $10 \mathrm{~mm}$. Nilai awal rata-rata kekuatan impact pelat baja St 37 sebelum dilakukan pengelasan SMAW adalah $5,41 \mathrm{~J} / \mathrm{mm}^{2}$ dengan struktur mikro ferit dan perlit yang berarti sifat awal dari baja St 37 adalah ulet. Setelah dilakukan pengelasan SMAW pada pelat baja St 37, nilai rata-rata kekuatan impact mengalami penurunan. Dari penelitian ini didapatkan hasil pengelasan paling optimal, yaitu pada kelompok kuat arus 100 A dengan nilai rata-rata kekuatan impact sebesar $0,96 \mathrm{~J} / \mathrm{mm}^{2}$. Pada kelompok kuat arus 100 A didapatkan struktur mikro ferit halus, bainit atas dan martensit sehingga hasil patahan menjukkan patah ulet-getas. Hasil pengelasan paling rendah didapat kelompok kuat arus 120 A dengan nilai rata-rata kekuatan impak sebesar $0,77 \mathrm{~J} / \mathrm{mm}^{2}$. Struktur mikro yang didapat pada kelompok 120 A adalah ferit kasar, bainit atas dan martensit sehingga hasil patahannya terlihat getas sepenuhnya.
\end{abstract}

Kata Kunci-Las SMAW; Kuat Arus; Kekuatan Impak; Struktur Mikro; Baja St 37.

\begin{abstract}
The journal describes the decrease in the impact force and the micro structure of the ST 37 steel plate after the SMAW welding. This research uses experimental methods and literary methods. The object in this study is the steel plate of St 37 which contains at least $0.12813 \%$ carbon. The number of specimens tested in this study was 27 which received a different strong current treatment. Welding uses electrode E 6013 with a strong variation of current $80 \mathrm{~A}, 100 \mathrm{~A}$ and 120 A. Weld joints Use a single $V$-junction with a angle of $70^{\circ}$. Each specimen that has been welded, is performed method of cooling with the oiltransmission medium for 15 seconds with a horizontal position. The oil used is Meditran $S$ with a new condition for each specimen of the current strong variation. The welded St 37 steel specimen has a thickness of $10 \mathrm{~mm}$. The average initial value of the strength of the steel plate impact of the St 37 before the SMAW welding is the $5.41 \mathrm{~J} / \mathrm{mm} 2$ with its micro-ferrite and perlit structures which means the initial nature of the St 37 steel is resilient. Having done welding SMAW on the steel plate of St 37, the average value of impact strength decreased. From this study obtained the most optimal welding results, namely in the strong group current $100 \mathrm{~A}$ with the average value of impact strength of $0.96 \mathrm{~J} / \mathrm{mm} 2$. In A Strong group of current 100 A acquired micro-ferrite structures, bainite over and martensitic so that the fault results present a resilient-getas fracture. The lowest result of welding is obtained by the current strong group of $120 \mathrm{~A}$ with an average value of impact strength of $0.77 \mathrm{~J} / \mathrm{mm} 2$. The micro structure obtained in the group of $120 \mathrm{~A}$ is coarse ferrite, bainite over and martensitic so that the results of the patency look completely brittle.
\end{abstract}

Key Words - Welding SMAW; Strong Currents; Power Impact; Micro Structure; Steel St 37.

\section{Pendahuluan}

Pengelasan (welding) adalah teknik penyambungan logam dengan cara mencairkan sebagian logam induk dan logam pengisi dengan atau tanpa logam penambah dan menghasilkan logam continue. Ada beberapa macam jenis las, dan yang paling sering digunakan dalam bidang rancang bangun adalah las Shielded Metal Arc Welding (SMAW) atau yang biasa disebut las busur listrik.

Las SMAW sering digunakan karena memliki banyak kelebihan, antara lain mudah pengoperasiannya, dapat digunakan untuk mengelas berbagai tipe sambungan, posisi, serta lokasi yang sulit dikerjakan, biaya pengoperasian yang relatif rendah, serta dapat dioperasikan di dalam maupun di luar ruangan. Namun, las SMAW juga memiliki beberapa kekurangan, antara lain hasil pengelasan sangat bergantung pada beberapa faktor. Faktor tersebut adalah juru las, jenis elektroda, kecepatan pengelasan, media pendingin dan kuat arus.

Kuat arus yang digunakan untuk pengelasan sangat berpengaruh terhadap kualitas hasil las. Jika penggunaan arus semakin besar maka proses pencairan logam yang akan disambung akan semakin cepat. Dampak dari penggunaan arus yang terlalu besar adalah membuat hasil rigi-rigi las bertambah lebar, jika bahan yang dilas itu tipis maka dapat menyebabkan benda kerja berlubang. Sedangkan jika arus yang digunakan terlalu kecil akan membuat busur elektroda 
sulit dinyalakan dan sering lengket terhadap benda kerja, sehingga berdampak pada pencairan logam yang disambung. Arus yang digunakan terlalu kecil menyebabkan pencairan logam yang disambung tidak akan menjadi sambungan yang baik antar logam yang akan disambung.

Untuk mendapatkan hasil sambungan las yang baik, perhitungan panas yang masuk (heat input) pada proses pengelasan merupakan salah satu hal yang perlu dikaji dengan seksama. Hal itu dilakukan dengan tujuan mendapatkan hasil yang lebih optimal dari kekuatan dan ketangguhan sambungan pengelasan. Heat input pada proses pengelasan akan sangat berpengaruh pada struktur mikro daerah las terutama nilai hardness dan impact. Hal ini disebabkan oleh kuat arus yang besar akan meningkatkan masukan panas. Pada umumnya struktur mikro akan mempengaruhi sifat mekanik logam. Jika terjadi perubahan struktur mikro, maka sifat mekanik yang dimilikinya akan berubah juga.

Penggunaan media pendingin pada proses pengelasan berfungsi untuk menentukan kecepatan pendinginan material setelah dilas. Laju pendinginan material yang telah dilas merupakan salah satu faktor untuk menentukan heat input yang ideal. Salah satu parameter untuk menentukan laju pendinginan (cooling time) ini disebut $\mathrm{T}(8 / 5)$, artinya waktu yang dibutuhkan untuk menurunkan temperatur lasan dari 800 ${ }^{\circ} \mathrm{C}-500{ }^{\circ} \mathrm{C}$ untuk beberapa jenis material adalah $10-25$ detik.

Kepekaan terhadap patah getas adalah masalah besar pada baja. Bila patah getas ini terjadi pada baja dengan daya tahan rendah, patahan tersebut dapat merambat dengan kecepatan sampai $2000 \mathrm{~m} /$ detik, yang dapat menyebabkan kerusakan dalam waktu yang sangat singkat sekali. Dalam hal sambungan las, patah getas ini menjadi lebih penting lagi karena adanya faktor-faktor yang membantu seperti: konsentrasi tegangan, struktur yang tidak sesuai dan adanya cacat dalam lasan. Berhubung dengan hal ini, maka dalam usaha mempertinggi keamanan las, perlu adanya penilaian ketahanan daerah las terhadap patah getas.

Struktur logam pada daerah pengaruh panas atau HAZ berubah secara berangsur dari struktur logam induk ke struktur logam las. Di dalam daerah pengaruh panas, besar butir dan struktur berubah sesuai dengan siklus termal yang terjadi pada waktu pengelasan. Pada daerah batas las di mana butir-butirnya sangat kasar logam menjadi sangat getas dan disebut penggetasan batas las. Ketangguhan yang paling baik didapat bila terbentuk struktur ganda dari martensit dan bainit bawah. Sedangkan bila terjadi bainit atas dan ferit kasar, ketangguhan baja menjadi sangat rendah. Perubahan struktur tersebut disebabkan oleh perbedaan sifat mampu-keras baja yang disebabkan karena adanya perbedaan komposisi kimia dan perbedaan kecepatan pendinginan karena panas pengelasan, pemeanasan mula, tebal pelat dan lain sebagainya.

Pengaruh struktur logam las terhadap ketangguhan pada dasarnya sama saja seperti pada batas las. Tetapi karena logam las dalam proses pengelasan ini mencair dan kemudian membeku, maka kemungkinan terjadi pemisahan komponen yang menyebabkan terjadinya struktur yang tidak homogen. Jadi jelas bahwa kecuali terjadinya pemisahan, pengaruh struktur terhadap ketangguhan logam las sama saja seperti pengaruh struktur terhadapa batas las, yaitu struktur bainit atas dan ferit kasar menurunkan ketangguhan dan struktur bainit bawah dan martensit mempertinggi ketangguhan.

Untuk mengetahui hasil las yang optimal, dalam penelitian ini variabel yang akan diteliti adalah media pendingin oli dan kuat arus (80 A, 100 A, 120 A) las SMAW. Kualitas hasil pengelasan pada sambungan las pelat baja St 37 dapat diketahui dengan uji impact dan struktur mikro.

\section{A. Pengertian Pengelasan}

Las (welding) adalah suatu cara untuk menyambung benda padat dengan jalan mencairkannya melalui pemanasan [16]. Pengelasan secara umum merupakan suatu cara untuk menyambung logam dengan menggunakan panas, tenaga panas pada proses pengelasan diperlukan untuk memanaskan bahan lasan sampai cair atau leleh sehingga bahan las tersebut dapat tersambung dengan atau tanpa kawat las sebagai bahan pengisi, karena pada kondisi pengelasan tertentu tidak memerlukan bahan pengisi pada proses pengelasan.

Prosedur pengelasan kelihatannya sangat sederhana, tetapi sebenarnya di dalamnya banyak masalah-masalah yang harus diatasi di mana pemecahannya memerlukan bermacammacam pengetahuan. Karena itu dalam pengelasan, pengetahuan harus turut serta mendampingi praktek.

\section{B. Kuat Arus Las SMAW}

Tahanan utama dalam lingkaran arus las terjadi pada busur las dan menentukan nilai kuat arus dan tegangan busur. Selanjutnya tahanan yang kecil terletak pada penghantar arus las (kabel-kabel las). Dengan demikian panjang pendeknya busur las menentukan kuat arus dan tegangan dalam lingkaran arus las.

\section{Heat Input}

Masukan panas (heat input) adalah besarnya energi panas pada tiap satuan panjang las ketika sumber panas bergerak [1]. Heat input pada proses pengelasan akan sangat berpengaruh pada mikrostruktur lasan dan HAZ terutama nilai hardness dan impact. Hal ini terjadi disebabkan oleh kuat arus yang terlalu besar akan meningkatkan masukan panas, sehingga memperlambat laju pendinginan.

Peningkatan heat input meningkatkan jumlah presentase ferrite acicular dan ketangguhan sambungan las. Heat input yang terlalu tinggi akan menyebabkan hot cracking dan yang terlalu rendah akan menyebabkan cold cracking.

\section{Media Pendingin}

Media pendingin (quenching) merupakan suatu substansi yang berfungsi dalam menentukan kecepatan pendinginan yang dilakuakan terhadap material yang telah diuji dalam perlakuan panas. Pemakaian media pendingin juga berguna dalam penentuan sifat dan fasa dari struktur yang terbentuk setelah material didinginkan.

Tujuan dari proses quenching adalah untuk mendapatkan kekerasan yang optimal. Kekerasan (hardness) adalah sifat mekanik yang berhubungan dengan kekuatan tarik dan merupakan fungsi dari kadar karbon dalam baja. 


\section{E. Pengujian Impact}

Pengujian impact merupakan suatu pengujian yang mengukur ketahanan bahan terhadap beban kejut (Yuwono, 2009:19).

Dasar pengujian impak ini adalah penyerapan energi potensial dari pendulum beban yang berayun dari suatu ketinggian tertentu dan menumbuk benda uji sehingga benda uji mengalami deformasi. Gambar di bawah ini memberikan ilustrasi suatu pengujian impak dengan metode charpy:

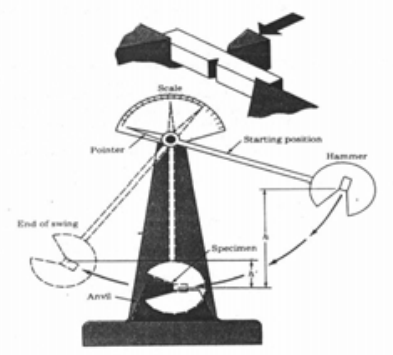

Gbr. 1 Ilustrasi Skematis Pengujian dengan Benda Uji Charpy

Pada pengujian impak ini, banyaknya energi yang diserap oleh bahan untuk terjadinya perpatahan merupakan ukuran ketahanan impak atau ketangguhan bahan tersebut. Pada gambar di atas dapat dilihat bahwa setelah benda uji patah akibat deformasi, bandul pendulum melanjutkan ayunannya hingga posisi $h$ '. Bila bahan tersebut tangguh, yaitu makin mampu menyerap energi lebih besar, maka makin rendah posisi $h$ '. Suatu material dikatakan tangguh bila memiliki kemampuan menyerap beban kejut yang besar tanpa terjadinya retak atau deformasi dengan mudah.

Pada pengujian impak, energi yang diserap oleh benda uji biasanya dinyatakan dalam satuan Joule dan dibaca langsung pada sakala (dial) penunjuk yang telah dikalibrasi yang terdapat pada mesin penguji. Harga impak (HI) suatu bahan yang diuji dengan metode charpy diberikan oleh:

$$
\text { HI }=\frac{\overline{8}}{A}
$$

di mana E adalah energi yang diserap dalam satuan Joule dan A adalah luas penampang di bawah takik dalam satuan $\mathrm{mm}^{2}$.

\section{F. Struktur Mikro}

Struktur mikro merupakan struktur yang dapat diamati di bawah mikroskop optik. Struktur mikro suatu logam dapat memberikan pengetahuan mengenai sifat-sifat atau perilaku dari logam ketikan akan digunakan untuk tujuan tertentu.

Pada umumnya struktur mikro dari baja tergantung dari kecepatan pendinginannya dari suhu daerah austenit sampai suhu kamar. Karena perubahan struktur ini maka dengan sendirinya sifat-sifat mekanik yang dimiliki juga berubah. Hubungan antara kecepatan pendinginan dan struktur mikro yang terbentuk biasanya digambarkan dalam diagram yang menghubungkan waktu, suhu dan transformasi (Continuous Cooling Transformation).

Di samping hubungannya dengan kekuatan, ternyata bahwa besar butir juga mempengaruhi energi patah (uji charpy) dan perambatan retak. Penelitian-penelitian menunjukkan bahwa makin halus butir-butir kristal, makin rendah suhu transisi ulet-getasnya. Karena itu tindakan memperhalus butir adalah tindakan tepat dalam usaha memperbaiki kekuatan dan ketangguhan baja ferit-perlit.

\section{METODE}

\section{A. Jenis Penelitian}

Penelitian ini menggunakan metode eksperimen, yaitu cara untuk mencari suatu hubungan sebab akibat antara beberapa faktor yang saling berpengaruh. Eksperimen dalam penelitian ini dilaksanakan di laboratorium dengan peralatan yang disesuaikan guna memperoleh data tentang pengaruh variasi kuat arus las SMAW dan media pendingin terhadap kekuatan impact dan struktur mikro sambungan V baja St 37 .

\section{B. Variabel Penelitian}

1. Variabel Bebas

Variabel bebas dalam penelitian ini adalah kuat arus pengelasan las SMAW (80 A, $100 \mathrm{~A}, 120 \mathrm{~A})$.

2. Variabel Kontrol

Dalam penelitian ini, variabel kontrol meliputi mesin las, operator las, jenis kampuh las, jenis elektroda, heat input, kecepatan pengelasan, media pendingin oli dan pelat baja St 37.

3. Variabel Terikat

Variabel terikat dalam penelitian ini adalah nilai kekuatan impact dan stuktur mikro hasil pengelasan.

\section{Pelaksanaan Penelitian}

1. Pembuatan Kampuh V

Penelitian ini menggunakan jenis kampuh $\mathrm{V}$ karena sangat sering digunakan dalam aplikasi konstruksi. Selain itu, luas penampang pada pengelasan kampuh $\mathrm{V}$ lebih luas daripada jenis kampuh yang lainnya sehingga memudahkan peneliti pada proses pengujiannya.

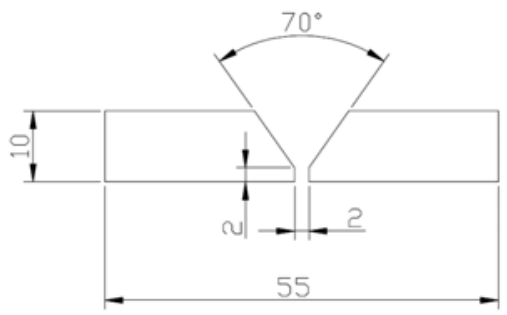

Gbr 2. Kampuh V Terbuka

Kampuh $\mathrm{V}$ dibentuk menggukanan gerinda tangan setelah bahan dipotong. Tepi permukan benda kerja diukur sedalam $2 \mathrm{~mm}$ lalu dibuat sudut $70^{\circ}$ seperti pada gambar di atas.

2. Proses Pengelasan Benda Kerja

a. Pengelasan dilakukan mengunakan arus 80, 100 dan 100 A. Elektroda yang digunakan yaitu E 6013 dan sambungan pengelasan menggunakan kampuh $\mathrm{V}$ tunggal sudut $70^{\circ}$.

b. Setiap spesimen yang sudah dilas, dilakukan proses pendinginan dengan menggunakan media pendingin oli. Oli yang digunakan adalah meditran $\mathrm{S}$ dengan kondisi yang masih baru pada setiap pencelupan spesimen pengelasan variasi kuat arus. Pencelupan dilakukan selama 15 detik ke dalam wadah yang sudah diisi oli 
dengan volume kurang lebih $1300 \mathrm{~mm}^{3}$. Spesimen dicelupkan dengan posisi horizontal.

3. Bentuk Spesimen Uji

Spesimen pada penelitian ini menggunan pelat baja $\mathrm{St}$ 37 yang akan dibentuk sesuai standar ASTM Vol. 03-03 E 23 untuk uji impact.

a. Bentuk material sesudah dilas

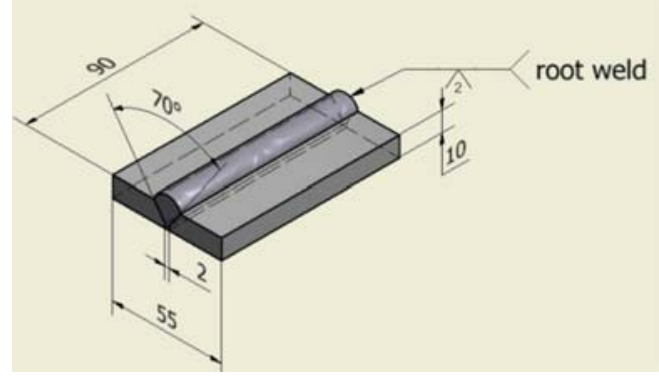

Gbr 3. Material Uji Impact Sesudah Dilas

b. Spesimen uji impact

Setelah proses pengelasan selesai, maka dilanjutkan pembuatan spesimen sesuai standar ASTM Vol 03-03 E 23 yang nantinya akan diuji impact.

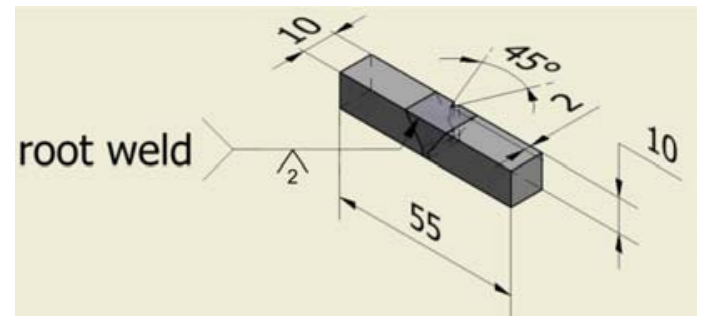

Gbr. 4 Spesimen Uji Impact (ASTM E 23)

4. Pengujian Impact

Setelah proses pengelasan dan pemotongan spesimen benda uji selesai dilakukan, selanjutnya dilakukan merusak (destructive testing) menggunakan metode pengujian impact metode charpy dengan berat bandul $26,32 \mathrm{~kg}$.

5. Foto Struktur Mikro

Sebelum melakukan pengujian foto struktur mikro, spesimen benda uji perlu dipoles terlebih dahulu. Pemolesan dengan menggunakan ampelas grade 80 sampai dengan 1500. Setelah spesimen diampelas dengan ukuran 1500 sampai halus kemudian diberi autosol agar spesimen lebih halus lagi.

Spesimen yang telah dipoles dilanjutkan dengan pengujian foto struktur mikro pada base metal, HAZ dan weld metal.

\section{HASIL DAN DISKUSI}

\section{A. Hasil Penelitian}

1. Pengaruh Kuat Arus Terhadap Kekuatan Impak

Hasil pengujian Impak setelah dilakukan pengelasan dengan alat penguji Charphy Impact Test Model JB-500S, kapasitas $500 \mathrm{~J}$, menggunakan standar ASTM E 23 dapat dilihat pada tabel V di bawah ini:
TABEL I

TABEL HASIL PENGUJIAN IMPACT

\begin{tabular}{|c|c|c|c|c|c|c|}
\hline Variabel & Sps & $\begin{array}{c}\text { Luas } \\
\left(\mathrm{mm}^{2}\right)\end{array}$ & $\begin{array}{c}\alpha \\
\left(^{\circ}\right)\end{array}$ & $\beta\left(^{\circ}\right)$ & $\begin{array}{c}\text { Energi } \\
\text { (J) }\end{array}$ & $\begin{array}{c}\text { HI } \\
\left(\mathrm{J} / \mathrm{mm}^{2}\right)\end{array}$ \\
\hline \multirow{3}{*}{$\begin{array}{c}\text { Raw } \\
\text { Material }\end{array}$} & 1 & 80 & 150 & 54 & 372,45 & 4,65 \\
\hline & 2 & 80 & 150 & 50 & 448,83 & 5,61 \\
\hline & 3 & 80 & 150 & 57 & 478,33 & 5,97 \\
\hline $\begin{array}{c}\text { Rata- } \\
\text { rata }\end{array}$ & & & & & 433,20 & 5,41 \\
\hline \multirow{9}{*}{$80 \mathrm{~A}$} & 1 & 80 & 150 & 119 & 73,04 & 0,91 \\
\hline & 2 & 80 & 150 & 118 & 74 & 0,92 \\
\hline & 3 & 80 & 150 & 119 & 73,04 & 0,91 \\
\hline & 4 & 80 & 150 & 117 & 74,25 & 0,92 \\
\hline & 5 & 80 & 150 & 110 & 77,05 & 0,96 \\
\hline & 6 & 80 & 150 & 122 & 72,51 & 0,90 \\
\hline & 7 & 80 & 150 & 110 & 77,94 & 0,97 \\
\hline & 8 & 80 & 150 & 125 & 70,01 & 0,87 \\
\hline & 9 & 80 & 150 & 125 & 71,99 & 0,89 \\
\hline $\begin{array}{c}\text { Rata- } \\
\text { rata }\end{array}$ & & & & & 73,76 & 0,91 \\
\hline \multirow{9}{*}{$100 \mathrm{~A}$} & 1 & 80 & 150 & 116 & 74,55 & 0,93 \\
\hline & 2 & 80 & 150 & 109 & 77,61 & 0,97 \\
\hline & 3 & 80 & 150 & 105 & 79,13 & 0,98 \\
\hline & 4 & 80 & 150 & 105 & 80,01 & 1 \\
\hline & 5 & 80 & 150 & 106 & 78,02 & 0,97 \\
\hline & 6 & 80 & 150 & 105 & 80,45 & 1,01 \\
\hline & 7 & 80 & 150 & 118 & 75,22 & 0,94 \\
\hline & 8 & 80 & 150 & 118 & 73,66 & 0,92 \\
\hline & 9 & 80 & 150 & 110 & 77,09 & 0,96 \\
\hline $\begin{array}{c}\text { Rata- } \\
\text { rata }\end{array}$ & & & & & 77,30 & 0,96 \\
\hline \multirow{9}{*}{$120 \mathrm{~A}$} & 1 & 80 & 150 & 130 & 61,25 & 0,76 \\
\hline & 2 & 80 & 150 & 130 & 61,92 & 0,77 \\
\hline & 3 & 80 & 150 & 127 & 69,21 & 0,86 \\
\hline & 4 & 80 & 150 & 130 & 62,95 & 0,78 \\
\hline & 5 & 80 & 150 & 136 & 51,92 & 0,64 \\
\hline & 6 & 80 & 150 & 128 & 64,56 & 0,80 \\
\hline & 7 & 80 & 150 & 133 & 58,85 & 0,73 \\
\hline & 8 & 80 & 150 & 128 & 66,02 & 0,82 \\
\hline & 9 & 80 & 150 & 130 & 63,12 & 0,78 \\
\hline $\begin{array}{c}\text { Rata- } \\
\text { rata }\end{array}$ & & & & & 62,20 & 0,77 \\
\hline
\end{tabular}

2. Pengujian Unsur Kimia

Unsur kimia pada baja dapat digunakan sebagai pemetaan masuk ke dalam manakah baja karbon St 37 ini. Unsur kimia baja karbon St 37 dapat dilihat pada tabel VI berikut:

TABEL II

TABEL UNSUR KIMIA BAJA ST 37

\begin{tabular}{|c|c|c|c|c|c|c|c|}
\hline Unsur & $\mathbf{C}$ & $\mathbf{S i}$ & $\mathbf{M n}$ & $\mathbf{P}$ & $\mathbf{S}$ & $\mathbf{N i}$ & $\mathbf{C r}$ \\
\hline $\mathbf{\%}$ & $\begin{array}{c}0,1 \\
283\end{array}$ & $\begin{array}{c}0,128 \\
58\end{array}$ & $\begin{array}{c}0,771 \\
67\end{array}$ & $\begin{array}{c}0,015 \\
71\end{array}$ & $\begin{array}{c}0,008 \\
02\end{array}$ & $\begin{array}{c}0,031 \\
32\end{array}$ & $\begin{array}{c}0,041 \\
12\end{array}$ \\
\hline Unsur & $\mathbf{M o}$ & $\mathbf{C u}$ & $\mathbf{S n}$ & $\mathbf{A s}$ & $\mathbf{A l}$ & $\mathbf{V}$ & $\mathbf{T i}$ \\
\hline $\mathbf{\%}$ & $\begin{array}{c}0,0 \\
00\end{array}$ & $\begin{array}{c}0,536 \\
9\end{array}$ & $\begin{array}{c}0,003 \\
46\end{array}$ & $\begin{array}{c}0,002 \\
40\end{array}$ & $\begin{array}{c}0,036 \\
88\end{array}$ & $\begin{array}{c}0,002 \\
49\end{array}$ & $\begin{array}{c}0,000 \\
01\end{array}$ \\
\hline
\end{tabular}

Dengan melihat unsur-unsur kimia yang terlihat di atas, ditinjau dari kandungan karbonnya, maka baja St 37 termasuk baja karbon rendah. 
3. Pengujian Struktur Mikro

Foto struktur mikro pada spesimen uji merupakan hasil pengamatan dengan pembesaran $400 \mathrm{X}$ sehingga dapat terlihat batas-batas butir. Berikut hasil pengujian struktur mikro:

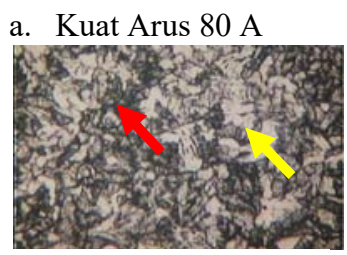

Base Metal

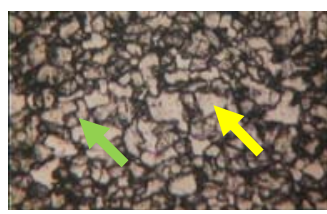

Heat Affected zone

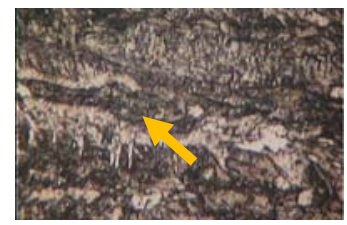

Weld Metal

Gbr. 5 Hasil Struktur Mikro 80 A

b. Kuat Arus $100 \mathrm{~A}$

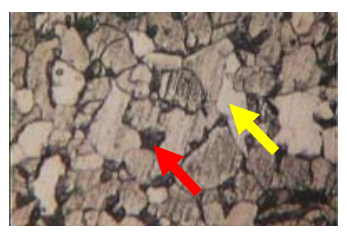

Base Metal

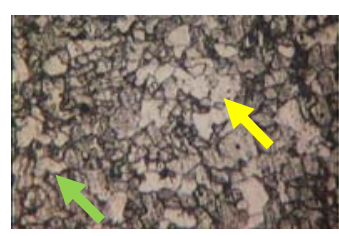

Heat Affected zone

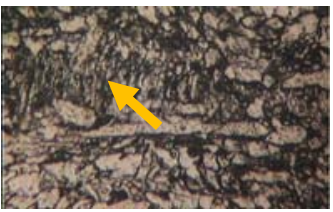

Weld Metal

Gbr. 6 Hasil Struktur Mikro 100 A

\section{c. Kuat Arus $120 \mathrm{~A}$}

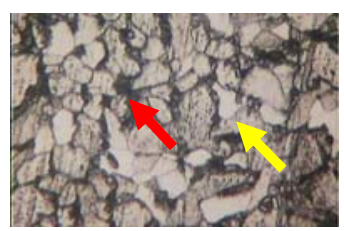

Base Metal

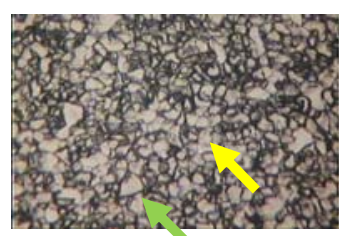

Heat Affected zone

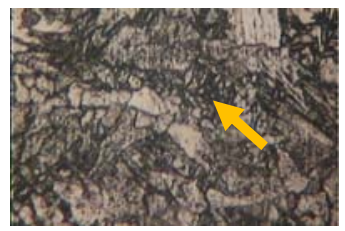

Weld Metal

Gbr. 7 Hasil Struktur Mikro 120 A
Keterangan:

$$
\begin{aligned}
& =\text { Ferit } \\
& =\text { Perlit }
\end{aligned}
$$

\section{B. Pembahasan}

1. Uji Impact

Hasil pengujian impak yang telah dilakukan terhadap sambungan las SMAW pada pelat baja St 37 menunjukkan bahwa harga impak raw material sebesar $5,31 \mathrm{~J} / \mathrm{mm}^{2}$, pada variasi arus $80 \mathrm{~A}$ sebesar $0,91 \mathrm{~J} / \mathrm{mm}^{2}$, variasi arus $100 \mathrm{~A}$ sebesar $0,96 \mathrm{~J} / \mathrm{mm}^{2}$ dan variasi arus 120 A sebesar 0,77 $\mathrm{J} / \mathrm{mm}^{2}$.

Dari hasil penelitan di atas dapat diketahui ada pengaruh kuat arus las SMAW dengan media pendingin oli terhadap baja St 37 . Harga impak mengalami kenaikan seiring dengan meningkatnya kuat arus dari 80 A sampai dengan arus $100 \mathrm{~A}$ dan penggunaan media pendingin oli membantu mempercepat laju pendinginan. Namun mengalami penurunan pada arus $120 \mathrm{~A}$. Hal ini disebabkan karena masukan panas yang dihasilkan semakin berlebih sehingga kecenderungan memberikan peneterasi yang lebih menonjol dan terkadang karena masukan panas yang terlalu tinggi akan menyebabkan logam las menjadi getas, sehingga ketika dilakukan pengujian impak nilai kekuatan impaknya mengalami penurunan. Masukan panas yang terlalu tinggi juga membuat laju pendinginan menjadi lambat sehingga memperbesar kemungkinan terjadinya penggetasan.

Penurunan kekuatan impak yang signifikan terlihat pada raw material dan kelompok variasi kuat arus. Hal ini disebabkan karena baja St 37 memiliki banyak macam unsur paduan dan tingginya unsur paduan. Salah satu unsur paduan yang erat kaitannya dengan penggetasan, yaitu phospor (P). Kadar P pada baja St 37 melebihi $0,006 \%$, yaitu sebesar $0,01571 \%$. Dengan tingginya kadar unsur paduan, maka terbentuknya struktur martensit dan bainit atas lebih besar sehingga mengurangi ketangguhan las dan tingkat penggetasan las jadi tinggi.

Nilai rentan penggetasan dapat dihitung melalui persamaan berikut:

$$
\begin{gathered}
\mathrm{UCS}=230 \mathrm{C}+190 \mathrm{~S}+75 \mathrm{P}+45 \mathrm{Nb}-12.3 \mathrm{Si}-5.4 \\
\mathrm{Mn}-1
\end{gathered}
$$

Jika nilai UCS $>30$, maka rentan penggetasan tinggi. Jika nilai $\mathrm{UCS}<10$, maka rentan penggetasan rendah. Dari perhitungan persamaan di atas untuk baja St 37 didapatkan nilai UCS 35,213>30, maka baja St 37 rentan penggetasan.

\section{Struktur Mikro}

Pengamatan metalografi bertujuan untuk mengetahui struktur mikro yang terdapat pada sebuah spesimen, sehingga memudahkan kita dalam menganalisa struktur mikro spesimen tersebut. Hasil pengujian ini merupakan data pendukung atau data penguat terhadap pengujian impak yang dilakukan. Pengelasan menggunakan media pendingin oli selama 15 detik untuk mendapatkan struktur bainit. Pada baja St 37 yang memiliki banyak unsur 
paduan dan tingginya unsur paduan, maka pada pendinginan cepat baja menjadi tangguh karena munculnya struktur bainit bawah. Sebaliknya, pendinginan lambat akan terbentuk struktur bainit atas [18].

Hasil foto mikro pengelasan kuat arus $80 \mathrm{~A}, 100 \mathrm{~A}$ dan 120 A dengan secara keseluruhan struktur dari logam induk (base metal) memiliki bentuk yang didominasi ferit (berwarna terang) dan perlit (berwarna gelap). Ferit mempunyai sifat yang lunak dan ulet. Hal ini didukung pada hasil patahan uji impak raw material yang terlihat ulet karena berwarna buram dan tidak memantulkan cahaya.

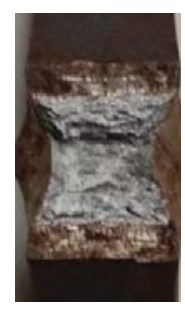

Gbr. 8 Patahan Raw Material

Saat terjadinya pengelasan yang menyebabkan adanya siklus thermal (pemananasan dan pendinginan cepat), hal ini sangat berpengaruh terhadap daerah HAZ maupun daerah las. Pada daerah HAZ arus 80 A dan 100 A mulai terlihat struktur bainit atas dengin bentuk pipih gelap. Munculnya struktur ini jika dilihat dari diagram CCT karena penggunaan media pendingin oli selama 15 detik dan karena unsur paduan baja St 37. Sedangkan bentuk ferit masih terlihat halus. Pada daerah las kuat arus $80 \mathrm{~A}$ dan $100 \mathrm{~A}$, mulai terlihat struktur martensit. Dengan struktur tersebut didapatkan sifat mekanik ulet-getas pada pengelasan kuat arus $80 \mathrm{~A}$ dan $100 \mathrm{~A}$. Berikut hasil patahannya:

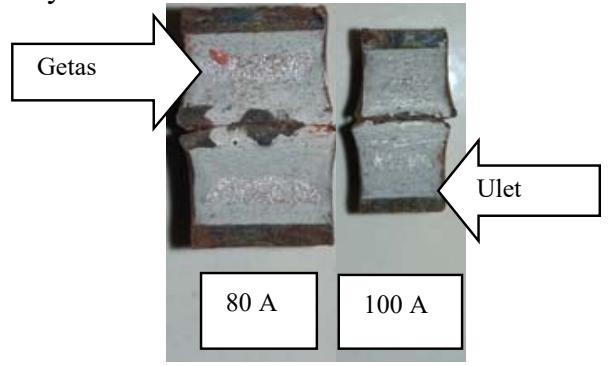

Gbr. 9 Patahan Kuat Arus 80 A dan 100 A

Pada daerah tengah patahan terlihat memantulkan cahaya yang berarti patahan tengah las adalah getas. Sedangkan pada daerah atas dan bawah patahan terlihat buram yang berarti patahan ulet.

Daerah HAZ Kuat arus 120 A terlihat juga struktur bainit bawah, tetapi struktur feritnya lebih kasar. Kuat arus 120 A memiliki laju pendinginan yang lebih lambat karena masukan panasnya lebih besar. Pada daerah lasnya juga terlihat struktur martensit. Hal ini yang menyebabkan bentuk patahan kuat arus 120 A getas sepenuhnya.

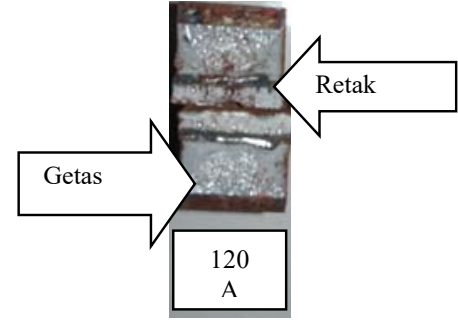

Gbr. 10 Patahan 120 A

Dapat dilihat pada gambar $11 \mathrm{di}$ atas bahwa bentuk patahan kuat arus 120 A lebih terlihat mengkilap dan memantulkan cahaya yang berarti patah getas. Pada gambar di atas juga terlihat retakan panas. Retakan ini biasa terjadi 48 jam atau beberapa menit setelah pengelasan. Retak ini terjadi karena adanya tegangan karena masukan panas yang terlalu tinggi sehingga menyebabkan sifat baja yang ketangguhannya turun. Paduan unsur seperti $\mathrm{Si}, \mathrm{Ni}, \mathrm{S}$ dan $\mathrm{P}$ juga akan meningkatkan kepekaan terhadap retak jenis ini. Usaha menghindari retak panas adalah menurunkan kadar Si dan $\mathrm{Ni}$ serendah mungkin dan menghilangkan kandungan $\mathrm{S}$ dan P sejauh mungkin [18].

\section{KESIMPULAN}

\section{A. Kesimpulan}

Berdasarkan hasil penelitian dan pembahasan pengelasan SMAW terhadap kekuatan impak baja St 37, maka dapat diambil kesimpulan yaitu ada pengaruh kekuatan impak dengan semakin bertambahnya kuat arus pengelasan, maka nilai impaknya semakin tinggi karena masukan panas yang dihasilkan mampu menyebarkan panas secara merata. Penggunaan media pendingin oli membantu mempercepat laju pendinginan. Tetapi panas yang berlebihan akan menyebabkan logam las menjadi getas dan memperlambat laju pendinginan sehingga nilai kekuatan impaknya menurun. Kekuatan impak tertinggi diperoleh dengan kuat arus $100 \mathrm{~A}$ sebesar $0,96 \mathrm{~J} / \mathrm{mm}^{2}$. Hal ini diperkuat dengan struktur mikro kuat arus 100 A yang muncul struktur bainit atas, martensit dan ferit halus sehingga mendapat patahan impak ulet-getas. Kekuatan impak terendah diperoleh kuat arus 120 A dengan kekuatan impak sebesar $0,77 \mathrm{~J} / \mathrm{mm}^{2}$. Hal ini juga diperkuat pada hasil struktur mikro kelompok kuat arus 120 A yang muncul struktur bainit atas, martensit dan ferit kasar sehingga patahan impaknya menjadi getas.

\section{B. Saran}

Saran yang diberikan sehubungan dengan penelitian ini, yaitu, jika mengelas pelat baja St 37 dengan tebal $10 \mathrm{~mm}$ menggunakan las SMAW dan media pendingin oli sebaiknya menggunakan kuat arus sedang, yaitu 100 A. Penggunaan kuat arus terlalu tinggi dapat menyebabkan penggetasan material semakin besar.

\section{REFERENSI}

[1] Indriyanto, Bayu dan Wijoyo. 2016. "Pengaruh Masukan Panas (Heat Input) Terhadap Ketangguhan Impak Sambungan Las TIG Al-13, 5Si”. Jurnal SIMETRIS. Vol. 7 (2): hal. 545-550. 
[2] Iswanto, Priyo Tri, Mudjijana dan Rela Adi Himarosa. 2017. "Karakterisasi Sambungan SMAW Baja Karbon Rendah Menggunakan 3 Jenis Elektroda". JMPM: Jurnal Material dan Proses Manufaktur. Vol. 1 (2): hal. 103-109.

[3] Kurniawan, Ary Setya, Solichin dan Rr. Poppy Puspitasari. 2014. "Analisis Kekuatan Tarik dan Struktur Mikro Pada Baja St.41 Akibat Perbedaan Ayunan Elektroda Pengelasan SMAW”. Jurnal Teknik Mesin. Tahun 22 (2): hal. 1-12.

[4] Laboratorium Pengujian Bahan. 2016. Buku Petunjuk Praktikum Uji Material. Malang: Jurusan Mesin Fakultas Teknik Universitas Brawijaya.

[5] Maulana, Yassir. 2016. "Analisis Kekuatan Tarik Baja St 37 Pasca Pengelasan dengan Variasi Media Pendingin Menggunakan SMAW". Jurnal Teknik Mesin UNISKA. Vol. 2 (1): hal. 1-8.

[6] Rahmadianto, Aditya Utama dan Susilo Adi Widyanto. 2015. "Rancang Bangun Bodi Mobil Tipe Urban Concept Berpenumpang Tunggal dengan Kapasitas Maksimum 70 kg". Jurnal Teknik Mesin S-1. Vol. 3 (2): hal. 85-92.

[7] Rasydy, Kharisma Yuko dan Suwarno. 2017. "Pengaruh Temperatur Austenisasi dan Proses Pendinginan Terhadap Struktur Mikro dan Sifat Mekanik Baja Paduan 05CcrMnSi”. Jurnal Teknik ITS. Vo. 6 (2): hal. 308-311.

[8] Setyo, Noor. 2011. "Pengaruh Viskositas Oli Terhadap Kekerasan dan Struktur Mikro Baja 60". Jurnal Jurusan Teknik Mesin Fakultas Teknik Universitas Tidar. Hal: 51-60.

[9] Siswanto, Rudi. 2018. Teknologi Pengelasan (HMKB791). Banjarmasin: Universitas Lambung Mangkurat.

[10] Sugiyono. 2010. Statistika Untuk Penelitian. Bandung: Alfabeta.
[11] Sugiyono. 2016. Metode Penelitian Kuantitatif, Kualitatif, dan R\&D. Bandung: Alfabeta.

[12] Suherman, Wahid. 1999. Ilmu Logam II. Surabaya: Jurusan Teknik Mesin FTI-ITS

[13] Sukaini. 2013. Teknik Las SMAW 1. Jakarta: Kementerian Pendidikan dan Kebudayaan.

[14] Tim Penyusun Buku Pedoman Penulisan Skripsi. 2014. Pedoman Penulisan Skripsi. Surabaya: Universitas Negeri Surabaya University Press.

[15] Triana, Tiara, Mursidil Kamil dan Yeni Muriani Zulaida. 2018. "Pengaruh Variasi Elektroda dan Arus Listrik Pengelasan Terhadap Cacat Las dan Sifat Mekanik Pelat Baja Aplikasi Lambung Kapal”. Flywheel: Jurnal Teknik Mesin Untirta. Vol. IV (2): hal. 50-55.

[16] Widharto, Sri. 2006. Petunjuk Kerja Las. Jakarta: Pradnya Paramita.

[17] Widharto, Sri. 2013. Welding Inspection. Bekasi: Mitra Wacana Media.

[18] Wiryosumarto, Harsono dan Toshie Okumura. 2000. Teknologi Pengelasan Logam. Jakarta: Pradnya Paramita.

[19] Yanuar, Padang dan Yurianto. 2016. "Evaluasi Weldability dan Temperatur Transformasi C-Mn Steel Produk Lokal Sebagai Bahan Baku Baja Tahan Aus". Jurnal Prosiding SNST Ke-7: 12-19.

[20] Yuwono, Akhmad Herman. 2009. Buku Paduan Karakterisasi Material 1 Pengujian Merusak (Destructive Testing). Depok: Departemen Metalurgi dan Material Fakultas Teknik Universitas 